\title{
110th Convention of the
}

\section{American Psychological Association}

\author{
Chicago, Illinois, August 22-25, 2002
}

Chicago is proud of its title as a "city of neighborhoods." The best way to get to know any city is to walk its streets, talk to the locals, browse through stores, and sample the city's foods. Chinatown, Little Italy, Greektown, Bucktown, River North, Gold Coast-you'll find everything here. Chicago has a wealth of ethnic culture, renowned museums, superb theater, and fabulous shops and restaurants, all tucked away in distinctive communities that together make it a feast for the senses. Shopping rivals that of New York City. The famed Magnificent Mile boasts some of the city's ritziest hotels, specialty boutiques, and restaurants along North Michigan Avenue. Miles of beautiful lakefront parks and riverside walkways offer a pleasant diversion from the hustle and bustle of the convention. There's much to choose from, so enjoy Chicago's offerings.

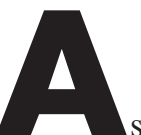

NEW CONVENTION!!! Beginning with the 2002 convention, APA is undertaking a new structure for its annual convention. In response to your requests, the annual convention will be shorterThursday through Sunday - and most of it will be located in one complex. There will be three levels of programming: divisional programming, topical tracks developed by groups of divisions, and plenary sessions. In addition, there will be more opportunities for earning continuing professional education credits. We hope you will join us for an exciting new meeting.

The 110th Convention of the American Psychological Association (APA) will be held in Chicago, Illinois, between August 22 and August 25, 2002. As stated in the Association Rules, the purposes of the annual convention are (a) to provide a forum in which members may present their scientific and scholarly work, (b) to present a general program that will be informative and of interest to all members of the association, (c) to facilitate the exchange of experience relating to the applications of psychology, and (d) to provide a place where the business of the association can be carried on efficiently.

Convention programs are developed by the several substantive divisions of APA and include symposia, paper and poster sessions, invited addresses, discussions, workshops, and so on. Meetings for the 110th convention are scheduled in the McCormick Place Convention Center, the Hilton Chicago Hotel, and the Hyatt Regency McCormick Place Hotel. Shuttle bus service will be provided to the McCormick Place Convention Center from the Hilton Chicago Hotel and the Hyatt Regency Chicago Hotel.

\section{Transportation}

Transportation from the Chicago O'Hare International Airport and the Midway Airport is available by taxicab and Airport Express bus. Taxicab fare is approximately $\$ 35$ from O'Hare and \$20-\$24 from Midway. The Airport Express buses provided by Continental Air Transport to the downtown hotels operate between 6:00 a.m. and 11:30 p.m. at both O'Hare and Midway (Website: http://www. airportexpress.com). The buses leave every 10 to $15 \mathrm{~min}-$ utes, and they cost $\$ 20$ one-way or $\$ 36$ round-trip from O'Hare and \$15 one-way or \$27 round-trip from Midway. The trip takes about 45 minutes from O'Hare and 30 minutes from Midway. Elevated train service from O'Hare to downtown Chicago is available on the Chicago Transit Authority (CTA) Blue Line for \$1.50; from Midway, elevated train service is available on the CTA Orange Line for $\$ 1.50$. Other ground transportation options can be found on the Website for the Chicago airports at http://www. ohare.com. For those driving to Chicago, 24-hour guest parking at the APA headquarters hotels costs between $\$ 23$ and $\$ 28$. Persons taking Amtrak to Chicago will arrive at Union Station, which is located at 210 South Canal Street. Note: All prices listed above are subject to change.

\section{Travel Tips}

The temperature in August in Chicago ranges from a high of $82{ }^{\circ} \mathrm{F}$ to a low of $61^{\circ} \mathrm{F}$. Chicago has an efficient public transportation system composed of the elevated trains and buses managed by the CTA. The six train lines (referred to as the "el") are indicated by color. The Blue, Green, Red, and Purple Line shuttles that service the suburb of Evanston run 24 hours a day. For both trains and buses, the rate for adults is \$1.50. CTA visitor passes give you unlimited rides on all CTA buses and trains for one price ranging from $\$ 5$ to $\$ 18$ - up to $65 \%$ off the cash fare-with one-, two-, three-, and five-day packages. Further information is available by calling (888) YOUR-CTA or at http://www. transitchicago.com. An $8.75 \%$ sales tax is charged for all items. Hotel rooms are taxed at $14.9 \%$. Note: All prices listed above are subject to change.

\section{Convention Program Availability}

The Convention Program will be mailed only to advance registrants and individuals who specifically request a program. Individuals who are not planning to attend the convention but who would like to receive a Convention Program should complete the mailing label found elsewhere in 
this section. Programs will be available in early to midJuly, after the advance convention registration deadline of July 5. Convention preregistrants should bring their copies of the program to the convention. There will be a charge of $\$ 5$ for additional copies of the program. Our supply of programs in Chicago will be limited. If you are uncertain about whether you will attend the convention, highlights of the program will appear in the May and June 2002 issues of the APA Monitor on Psychology.

\section{Airline Information}

APA has selected United Airlines and Delta Air Lines as the official air carriers for the 2002 convention in Chicago.

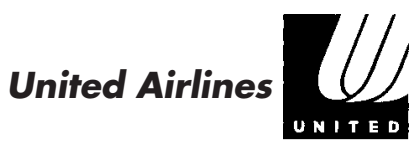

United Airlines is offering special discounts for the APA convention in Chicago. You may choose a 5\% discount off any United domestic published airfare or a $10 \%$ discount off the unrestricted midweek coach fare. As an extra bonus, an additional $5 \%$ discount is available if you purchase your tickets at least 60 days in advance of travel. Or you may choose Area Pricing, a fixed airfare rate to the meeting based on geographical location. Area Pricing must be purchased at least 7 days in advance. These discounts apply on United Airlines, Shuttle by United, and United Express flights. Reservations should be made as early as possible. Seats are limited. Restrictions may apply. Fares are guaranteed at the time of ticket purchase. Simply call or have your travel agent call United's toll-free number noted below for reservations and assistance.

Continental United States, Hawaii, and Canada

United Airlines (daily from 7 a.m. to 12 midnight, Eastern time)

(800) 521-4041

Refer to Meeting ID number 597BD.

\section{A. Delta Air Lines}

Delta Air Lines is offering a 5\% discount off Delta's published round-trip fares within the continental United States, Hawaii, Alaska, Canada, Mexico, Bermuda, San Juan, Nassau, and the U.S. Virgin Islands. By purchasing your ticket 60 days or more prior to your departure date, you can receive an additional 5\% bonus discount. Applicable restrictions must be met. Seats are limited. No discounts apply on Delta Express.

A $10 \%$ discount will be offered on Delta's domestic system for travel to the meeting, based on the published unrestricted round-trip coach rates. No advance reservations or ticketing is required, but if you purchase your ticket 60 days or more prior to your departure date, you can receive an additional $5 \%$ bonus discount. No discounts apply on Delta Express.

Special guaranteed round-trip Zone Fares are also available to all cities served by Delta and Delta Express in the continental United States, Hawaii, Alaska, Canada, Mexico, Bermuda, San Juan, Nassau, and the U.S. Virgin Islands for savings on midweek travel to the meeting. There is a two-day minimum stay, and no Saturday night stay is required. Only seven days advance reservations and ticketing are required. Fares are fully refundable, less an administrative service fee. Note: Zone fares are not valid for travel to a destination served only by a Delta Connection carrier.

To take advantage of these discounts, call or have your travel agent call the number noted below for reservations and assistance.

\section{Continental United States, Hawaii, and Canada}

Delta Meeting Network Reservations (weekdays from 7:30 a.m. to 11:00 p.m. or weekends from 8:30 a.m. to 11:00 p.m., Eastern time)

(800) 241-6760

Refer to Delta File Number 160117A.

\section{Convention Registration}

Beginning March 15, 2002, register online on APA's Website at http://www.apa.org/convention/. Convention attendees are urged to register for the meeting in advance. Advance registration not only assists APA in planning for the convention but also allows savings for the registrants.

Registration fees are required to support the costs associated with the convention, as well as to comply with the association's rule that the convention be a self-sustaining service of the association. Persons who request a replacement badge during the convention will be charged $\$ 2$ each time the request is made. Nonmember spouses/equivalents and dependents under age 18 may register by paying a nonrefundable processing fee of $\$ 5$ per person if their names appear on the registration form of a fee-paying registrant. The registration fees for the 2002 convention are as follows:

For those registering in advance (before July 5, 2002)

$\$ 165$ APA member, fellow, or associate; APA international affiliate

$\$ 195$ Nonmember of APA

$\$ 50 \quad$ APA student affiliate

$\$ 75$ Full-time student,

APA high school teacher affiliate

\$5 Nonrefundable processing fee for nonmember spouses/equivalents and dependents under age 18, if noted on the form of a fee-paying registrant

For those registering on-site in Chicago

\$220 APA member, fellow, or associate; APA international affiliate

$\$ 250$ Nonmember of APA

$\$ 60 \quad$ APA student affiliate

$\$ 85$ Full-time student, APA high school teacher affiliate 
Nonrefundable processing fee for nonmember spouses/equivalents and dependents under age 18, if noted on the form of a fee-paying registrant

The convention badge, with name and institutional affiliation; the Expocard; and the Convention Program will be mailed in advance of the convention to those who preregister. Advance registrants need only obtain a badge holder at the APA registration area in Chicago to complete the procedure and thus avoid delays. In addition, the APA Exhibit Hall will be restricted to persons who are wearing badges.

Complete registration facilities will be maintained at McCormick Place, Lakeside Center, Level 3, Hall D1, according to the following schedule:

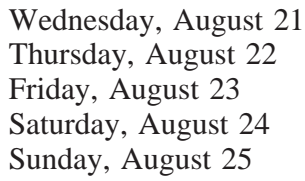

3:00 p.m. to 8:00 p.m. 7:00 a.m. to $6: 00$ p.m. 8:00 a.m. to 5:00 p.m. 8:00 a.m. to 5:00 p.m. 8:00 a.m. to $12: 00$ noon

Because of administrative delays, APA will not accept purchase orders for payment of convention registration fees.

Refund policy: Advance registrants who are unable to attend the convention may request a refund of their registration fee if a written request is received before August 25, 2002. A full refund of the registration fee will apply to requests received by July 5, 2002; a 75\% refund will apply to requests received between July 5 and August 10, 2002; a 50\% refund will apply to requests received between August 10 and August 25, 2002. After August 25, 2002, no refunds will be issued.

\section{Housing}

\section{FLASH!!! IMPORTANT!!!}

Hotel reservations may be made DIRECTLY through the APA's housing service, ExpoExchange, by Internet, fax, mail, or phone beginning on March 15, 2002. Only Advance Convention Registration Forms are to be sent to APA for processing.

In cooperation with APA, all of the APA hotels have set aside substantial blocks of rooms. These rooms for the convention are available only when reservations are made through ExpoExchange. To take advantage of the special APA room rates for the convention, be sure to book your reservations through ExpoExchange by July 25, 2002. After July 25, 2002, the official APA blocks will be released, and the hotels may charge significantly higher rates. Hotel rooms for persons arriving in the city at the last minute will probably be expensive, scarce, or nonexistent. To ensure having a room in an APA hotel, we strongly recommend that individuals obtain hotel reservations early.

During past conventions, the headquarters hotels have been filled by early May. It is anticipated that the headquarters hotels will also be filled early in Chicago. Housing requests received toward the end of the advance registration period have typically been assigned alternate housing.

Registrants should bear in mind that rooms are assigned on a first-come, first-served basis. All rates are per room night and are subjected to a $14.9 \%$ tax (subject to change). Bedding preferences and other special requests will be assigned by the hotels at check in. There is no guarantee that persons will obtain a room in the specific hotel requested, in the type of room requested, or at the rate requested. If accommodations are not available at the hotel of your choice, comparable reservations will be made at other contracted hotels.

Please note that the availability of rooms for those arriving before August 22 may be limited. Therefore, if you are attending preconvention activities, ExpoExchange will make every effort to accommodate your needs but cannot guarantee rooms for those with early arrival dates.

Reservations can be made through ExpoExchange by Internet, telephone, fax, or mail beginning on March 15, 2002. Requests received after July 25,2002 , will be processed on a space-available basis. To reserve a room for the APA convention choose ONE of the following methods:

Internet: Fill out the Hotel Reservation Form and use the interactive Web site at http://www.apa.org/convention/ to submit the form directly;

$$
\text { or }
$$

Telephone: Call ExpoExchange, Monday-Friday, 8 a.m.-5 p.m., Central time, at (800) 424-5249 (toll free) or (847) 940-2155 (international). Phone reservations are limited to five per call;

or

Fax: Send a completed Hotel Reservation Form, using one form per reservation request, to (800) 521-6017 or (847) 940-2386;

or

Mail: Send a completed Hotel Reservation Form, using one form per reservation request, with the required deposit (credit card or check) to ExpoExchange, 108 Wilmot Road, Suite 400, Deerfield, IL 60015. Make checks payable to "ExpoExchange." Checks must be from a U.S. bank and in U.S. dollars. No wire transfers will be accepted.

ExpoExchange will send you a confirmation. Review it carefully for accuracy. Room confirmation will be sent only to the primary person requesting the reservation. If you do not receive a confirmation by E-mail, fax, or mail within 14 days of sending your request, please contact ExpoExchange at (800) 424-5249 or (847) 940-2155.

All hotels require a deposit of $\$ 175$ per room, $\$ 350$ per one-bedroom suite, or $\$ 525$ per two-bedroom suite. Payment can be made by providing an American Express, VISA, MasterCard, Discover, or Diners Club credit card number on your Hotel Reservation Form or by including a check made out to "ExpoExchange." Credit card deposits will be charged IMMEDIATELY. Please note, if a deposit is not received, your hotel reservation will not be processed. 
Persons sharing a room are requested to send in only one Hotel Reservation Form with the names of all of the occupants of the room. By law, there is a limit of four persons to a room, and some hotels will not accept reservations for four persons in a room. Room confirmation will be sent only to the person requesting the reservation. Colleagues wishing to stay in the same hotel should submit their forms in the same envelope.

Changes/Cancellations/Refunds: Changes or cancellations made on or before July 25, 2002, should be made directly with ExpoExchange and will be refunded in full. ExpoExchange will issue the refund. Changes or cancellations made after 5:00 p.m. Central time, on July 25, 2002, are subject to a $\$ 21.00$ processing fee. Deposits will be completely nonrefundable within your assigned hotel's cancellation policy. Please review your hotel confirmation for your hotel's nonrefundable policy. After August 9, 2002, contact the hotels directly.

\section{Headquarters Hotels}

Hilton Chicago Hotel: Large deluxe convention hotel. Located on Michigan Avenue overlooking Grant Park and Lake Michigan, just five minutes from McCormick Place. Restaurants and bars, shopping arcade, beauty shop, and barber on the property. Indoor pool and health club. Complimentary shuttle service to shopping on Michigan Avenue. Twenty-four-hour guest parking (valet, \$28; self-park, $\$ 23)$. Five-minute cab ride to McCormick Place. APA shuttle bus to McCormick Place will pick up and drop off at the Balbo Street entrance.

Hyatt Regency McCormick Place Hotel: Contemporary business-class hotel with tastefully appointed guestrooms and direct access to McCormick Place. Coin-operated laundry on the fourth floor next to the health club. Complimentary shuttle service to the Shedd Aquarium, the Art Institute of Chicago, Water Tower Mall, and Navy Pier; contact the concierge or bell stand for a schedule. Indoor pool and full-service health club with a sundeck. Twenty-four-hour guest parking (valet, $\$ 27$; hourly self-park, $\$ 18.50$ for three to nine hours).

\section{Supplemental Hotels}

Best Western Inn of Chicago: Newly renovated fullservice hotel located just one half block east of North Michigan Avenue, Chicago's Magnificent Mile. Convenient to business and financial centers, nightlife, museums, galleries, restaurants, and shopping. Rooftop terrace with great views of downtown Chicago. Fitness center. Twentyfour-hour guest parking (valet, \$24; self-park, \$22; no in-and-out). Ten-minute cab ride to McCormick Place.

Essex Inn: Completely renovated in 1999, this hotel is one of the three closest properties to McCormick Place. Walking distance to Museum Campus, Soldier Field, the Art Institute of Chicago, Symphony Center, and downtown shopping. Guest shuttle to Water Tower Place. Outdoor pool and health club. Twenty-four-hour valet guest parking (\$20). Five-minute cab ride to McCormick Place.
Executive Plaza Hotel: Located by the Chicago River on Wacker Drive, three quarters of the hotel's 420 rooms will have been renovated. Has outstanding views and is within walking distance to restaurants and nearby attractions. Fitness center. Twenty-four-hour valet guest parking (\$28). Ten-minute cab ride to McCormick Place.

Hyatt Regency Chicago Hotel: Recently renovated, large convention hotel located on Chicago's Magnificent Mile. Exercise room, beauty salon, and barber on property. Twenty-four-hour guest parking (valet or self-park, \$33). Ten-minute cab ride to McCormick Place. APA shuttle bus to McCormick Place will pick up and drop off at the East Tower Wacker Drive entrance.

Palmer House Hilton Hotel: Historic lankmark hotel in the heart of Chicago's financial district. Within walking distance to numerous downtown restaurants, shops, and museums. Indoor pool and health club, shopping arcade, beauty parlor, and barber. Twenty-four-hour guest parking (valet, \$32). Ten-minute cab ride to McCormick Place.

Sheraton Chicago Hotel and Towers: Modern deluxe convention hotel on the Chicago River. Health club and indoor swimming pool (\$8 per day, $\$ 15$ per stay). Twentyfour-hour guest parking (valet, \$32; self park, \$23.50). Ten-minute cab ride to McCormick Place.

Swissôtel Chicago Hotel: Deluxe hotel with contemporary decor. Adjacent to Illinois Center golf course and driving range and within walking distance to wonderful shopping along Michigan Avenue. European health spa with swimming pool (\$10.80 per day). Twenty-four-hour valet guest parking (\$33). Ten-minute cab ride to McCormick Place.

Note: Parking rates are subject to change without notice.

\section{Family Plan Accommodations}

The many attractions available in Chicago make it an ideal vacation spot for families. For registrants bringing their families, family plan accommodations are available at the hotels noted below. Children under the ages stated below may stay with their parent or parents without charge, if no additional equipment is brought into the room. Some hotels have rooms with two double beds, which need to be requested on your housing form. See hotel descriptions for information on limited space and bedding. When completing the Hotel Reservation Form, registrants must indicate the number and ages of the children and must request family plan accommodations.

Under 12 years of age

Hyatt Regency McCormick Place Hotel

Under 16 years of age

Hyatt Regency Chicago Hotel 
Under 18 years of age

Essex Inn

Executive Plaza Hotel

Hilton Chicago Hotel

Sheraton Chicago Hotel and Towers

Swissôtel Chicago Hotel

\author{
No age limit \\ Best Western Inn of Chicago \\ Palmer House Hilton Hotel
}

\section{Green/Environmentally Friendly Hotels}

The following hotels are currently participating in the American Hotel and Motel Association's "Good Earthkeeping Program" or are committed to the environment and practice energy and resource conservation:

Hilton Chicago Hotel

Swissôtel Chicago Hotel

\section{Arrangements for Persons With Disabilities}

The APA Council of Representatives has adopted "Guidelines on Physical and Social Accessibility," prepared by the APA Task Force on Psychology and the Handicapped. In compliance with these guidelines, the Board of Convention Affairs asks each person with a disability who is planning to attend the convention to identify himself or herself and to provide information on how APA can make the convention more accessible for him or her. Please check the appropriate box on the Advance Convention Registration and Hotel Reservation Forms if you are disabled and would like assistance in facilitating your attendance at the convention. A note outlining your specific needs should accompany the Advance Convention Registration and Hotel Reservation Forms. APA will provide a van with a lift as transportation for persons who use wheelchairs, interpreters for hearing-impaired individuals, and escorts/readers for persons with visual impairments, if specific requests are provided at the time of advance registration. During the convention, persons with disabilities who desire a place to relax or who desire assistance with wheelchair repairs, readers, escorts, interpreters, and so on may visit the APA Resource Room for Persons With Disabilities.

To facilitate hotel reservations for those who need wheelchair accessibility and visual or hearing aids, the Board of Convention Affairs has compiled information on the headquarters hotels. It is strongly suggested that persons who are in need of wheelchair-accessible accommodations request housing at one of the following hotels. Additional information regarding accessibility of supplemental hotels and a detailed report on accessibility of headquarters facilities may be obtained from the APA Convention Office in Washington, DC.

\section{Hilton Chicago Hotel}

Main entrance: Balbo Street; automatic door.
Restrooms: The most accessible public restrooms are on the lobby level next to Buckingham's Restaurant and on the second floor opposite the Normandie Lounge.

Sleeping rooms: 20 rooms are designed for wheelchair accessibility; 5 have roll-in showers. There are no rooms with two beds and roll-in showers.

Meeting rooms: Lifts to access the Continental Ballroom and the Boulevard Room are available. South elevator provides access to the International Ballroom-Main Floor. One portable lift and a ramp are available for use in the meeting rooms.

Restaurants: Accessible.

Aids: Assisted-listening devices are available; shower benches are available.

Health club: Accessible, but the ramp at the entrance is very steep and long; a hoist is available for the indoor pool. Shuttle: The hotel provides a wheelchair-accessible complimentary shuttle service to shopping on Michigan Avenue.

\section{Hyatt Regency McCormick Place Hotel}

Main entrance: Accessible.

Restrooms: Accessible.

Sleeping rooms: 25 rooms are designed for wheelchair accessibility; 13 have roll-in showers. Rooms are not recommended for those using power chairs or scooters. Four rooms have been modified for the hearing impaired. Guest service guides are available in braille.

Meeting rooms: Accessible.

Restaurants: Accessible and braille menus are available. Aids: A limited number of telecommunications devices for the deaf (TDDs) are available; bath benches are available.

Rooms designed for wheelchair accessibility are also available at the Hyatt Regency Chicago Hotel and the Swissôtel Chicago Hotel. However, it is strongly suggested that persons who are in need of wheelchair-accessible accommodations request housing at one of the headquarters hotels.

\section{Employer Exhibit Booths}

Job opportunities for attendees can be found in the APA Exhibit Hall. Employer exhibit booths will be located in a section of the APA exhibits in McCormick Place, Lakeside Center, Level 3, Hall D1. Employers who are interested in obtaining a booth may request information from Jodi Ashcraft, Exhibits Manager, American Psychological Association, 750 First Street, NE, Washington, DC 20002-4242 (telephone: 202-336-5565).

\section{Child Care}

For financial reasons, APA will not be providing on-site facilities for a children's hospitality center in Chicago. Parents who require child care during the convention may make arrangements with existing child-care services in Chicago. Although APA is providing the name of a resource that is located in Chicago, APA is not endorsing this company or liable for services provided by it. Parents may call directly to make arrangements in advance. 
American ChildCare Services, Inc., 445 East Ohio Street, Suite 306, Chicago, IL 60611; (312) 644-7300: Child-care providers will care for children in their hotel rooms or will take children on outings in the city. Fees: $\$ 15.50$ per hour per family with a four-hour minimum. Transportation for each sitter is $\$ 5.00$ round trip; sitters at Hyatt Regency McCormick Place Hotel will require a $\$ 10.00$ transportation fee. After midnight, transportation is an additional \$5.00. Method of payment must be VISA, MasterCard, American Express, or Discover credit card. Because of the time of the year, reservations for child care must be made by August 12, 2002. A fee of $\$ 22.00$ will be imposed for any cancellation made within 24 hours of the starting time.

\section{Continuing Professional Education Workshops}

Continuing Professional Education Workshops, designed to offer a broad array of continuing education topics for practitioners and scientists, will be offered during the convention. Sponsored by the APA Continuing Professional Education Committee, the workshops are designed to upgrade the skills and knowledge of clinicians, academics, and those in research. Participants earn continuing education credits for these workshops. All workshops are scheduled for either a half day (four hours) or a full day (seven hours). Complete information about the activities offered and an enrollment form will be in a special tear-out booklet in the May 2002 issue of the Monitor on Psychology. Call the Continuing Professional Education Office at (800) 3742721, extension 5991, if you have any questions prior to that time.

\section{Convention Personnel}

You may wish to contact one or more of the following persons before or during the convention:
Chair, Board of Convention Affairs: William C. Howell, c/o Convention Office, American Psychological Association, 750 First Street, NE, Washington, DC 20002-4242.

Director, Convention/Meetings: Candy Won, American Psychological Association, 750 First Street, NE, Washington, DC 20002-4242. (202) 336-6020.

Continuing Professional Education Program: Continuing Professional Education Office, American Psychological Association, 750 First Street, NE, Washington, DC 200024242. (202) 336-5991.

\section{Mailing Label for Convention Program}

If you will definitely not attend the convention and would like to order a copy of the Convention Program, please fill out the label below and return it to the Convention Office, American Psychological Association, 750 First Street, NE, Washington, DC 20002-4242. Your program will be mailed in late July or August. Advance registrants and on-site registrants will automatically receive copies.

Cut along dashed lines.

\section{Print Only-Zip Code Is Imperative}

Name

Mailing Address

City

State Zip Code 